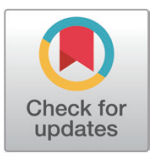

\#These authors contributed equally to this work.

*Corresponding author

Seung Hwan Lee

Division of Animal and Dairy Science,

Chungnam National University,

Daejeon 34134, Korea.

Tel: +82-42-821-5772

E-mail: slee46@cnu.ac.kr

Bong Hwan Choi

Animal Genomics \& Bioinformatics

Division, National Institute of Animal

Science, RDA, Wanju 55365, Korea.

Tel: +82-63-238-7304

E-mail: bhchoi@korea.kr

Copyright @ 2020 Korean Society of

Animal Sciences and Technology.

This is an Open Access article

distributed under the terms of the

Creative Commons Attribution

Non-Commercial License (http://

creativecommons.org/licenses/by-

$\mathrm{nc} / 4.0 /$ ) which permits unrestricted

non-commercial use, distribution, and

reproduction in any medium, provided

the original work is properly cited.

ORCID

Soo Hyun Lee

https://orcid.org/0000-0001-5257-2068

Dongwon Seo

https://orcid.org/0000-0003-0548-7068

Doo Ho Lee

https://orcid.org/0000-0002-2174-7897

Ji Min Kang

https://orcid.org/0000-0002-4907-2203

Yeong Kuk Kim

https://orcid.org/0000-0002-6530-2304

Kyung Tai Lee

https:// orcid.org/0000-0003-0990-4818

Tae Hun Kim

https:// orcid.org/0000-0003-1621-3281

Bong Hwan Choi

https:// orcid.org/0000-0002-4795-3285

Seung Hwan Lee

https://orcid.org/0000-0003-1508-4887

\section{Erratum to: Comparison of prediction accuracy for genomic estimated breeding value using the reference pig population of single-breed and admixed-breed}

\author{
Soo Hyun Lee ${ }^{1 \#}$, Dongwon Seo ${ }^{1 \#}$, Doo Ho Lee ${ }^{1}$, Ji Min Kang ${ }^{1}$, Yeong Kuk Kim", \\ Kyung Tai Lee ${ }^{2}$, Tae Hun Kim², Bong Hwan Choi ${ }^{2 *}$ and Seung Hwan Lee ${ }^{1 *}$ \\ ${ }^{1}$ Division of Animal and Dairy Science, Chungnam National University, Daejeon 34134, Korea \\ ${ }^{2}$ Animal Genomics and Bioinformatics Division, National Institute of Animal Science, RDA, Wanju 55365, Korea
}

\section{ERRATUM}

In the published article "Comparison of prediction accuracy for genomic estimated breeding value using the reference pig population of single-breed and admixed-breed. J Anim Sci Technol. 2020;62(4):438448. https://doi.org/10.5187/jast.2020.62.4.438," the acknowledgements have to be modified. The editorial office will report that this amendment is made at the request of the author.

\section{ACKNOWLEDGEMENTS}

This research was partly supported by Basic Science Research Program through the National Research Foundation of Korea (NRF) funded by the Ministry of Education (No. NRF-2019R1F1A1057605). All the data-set (Phenotypes and genotypes) used in this study was provided by National Institute of Animal Science, Rural Development Administration (RDA). Berkshire samples were provided by Dasan Pig Breeding Farm, Namwon, Korea

\section{REFERENCE}

1. Lee SH, Seo D, Lee DH, Kang JM, Kim YK, Lee KT, Kim TH, Choi BH, Lee SH. Comparison of prediction accuracy for genomic estimated breeding value using the reference pig population of single-breed and admixed-breed. J Anim Sci Technol. 2020;62:438-48. https://doi.org/10.5187/ jast.2020.62.4.438 